\title{
Triterpenoid compound from metanol extract of mangrove leaves (Sonneratia alba) and anti-cholesterol activity test
}

\author{
Weny J.A Musa ${ }^{1}{ }^{*}$, Nurhayati Bialangi ${ }^{1}$, Boima Situmeang ${ }^{2}$, Saronom Silaban ${ }^{3}$ \\ 'Department of Chemistry, Faculty of Mathematic and Natural Science, Gorontalo State University, Indonesia \\ ${ }^{2}$ Department of Chemistry, Sekolah Tinggi Analis Kimia Cilegon, Cilegon, Indonesia \\ ${ }^{3}$ Department of Chemistry, Faculty of Mathematic and Natural Science, Universitas Negeri Medan, Medan 20221, Indonesia
}

Received: 30 April 2019; Accepted: 05 Mei 2019

\begin{abstract}
:
Mangrove plant (Sonneratia alba) is easily found in West and North Indonesia. Mangrove plant has the potential of being a herb medicine. Mangrove plant variously used in ethnomedicine to treat various deseases like wounds, diarrhea, and fever. In previously sutudy, leaf extract of mangrove plants reported have anti-cholesterol activity. This plant is widely used to treat various deseases like wounds, diarrhea, and fever. The purpose of this study was to isolate triterpenoid compound from the ethyl acetate fraction of mangrove leaves and anticholesterol activity test. Extraction was done by maceration method using methanol $96 \%$ as solvent. Isolation was carried out by column chromatography using a combination of $n$-hexane, ethyl acetate, and methanol solvents. The elucidation of the structure was determined by analysis of IR, 'H-NMR, ${ }^{13} \mathrm{C}-\mathrm{NMR}, 2 \mathrm{D}-\mathrm{NMR}$, and MS spectroscopies as well as by comparisons with the literature. Anticholesterol activity test was carried out in vitro. The results showed that triterpenoid compounds (lupeol) were able to reduce cholesterol from concentrations of 5, 10, 20, 40, 60, and 80 ppm are 13.7; 29.4; 49.0; 60,1; 70.2; and 77.0\% respectively. Therefore, isolates compound (lupeol) have anti-cholesterol activity.
\end{abstract}

Keywords:

Anti-cholesterol; mangrove; triterpenes

\section{Introduction}

Mangrove plants (Sonneratia alba) are a group of plants that have high or shrubs and grow in tropical and subtropical coastal areas. This plant has a distinctive morphological features and can survive in environments with high salinity (Analuddin et al. 2018). Some mangroves have been used as herbs and extracts have biological activity in humans, animals, and phatogen bacteria.

Sonneratia alba is one of mangrove plants in the family of lythraceae. Sonneratia alba widely distributed in the coastal regions of Southeast Asia and the Indian Ocean. This plant has been used traditionally in coastal communities of Indonesia to treat of wounds, diarrhea, and fever deseases (Prabhu \& Guruvayoorappan, 2012). In previous study, phytochemical investigation Sonneratia alba has been reported contained triterpenoid, steroid,

\footnotetext{
* Corresponding author.

wenymusa@ung.ac.id

doi: https://doi.org/10.2 4114/jpkim.v1li 1.13124
}

and flavonoid compounds (Kumar et al. 2011; Musa et al. 2018).

The trend of eating practical and instant foods like fast food and preserved food has developed rapidly in the community. The types of this food can harm the human bodies, because it contains saturated fatty acids and high cholesterol. Cholesterol is an essential compound for the body to synthesize important substances, such as cell membranes, and insulating materials for nerve cells, as well as sex hormones and kidney children. Based on WHO data (2011) cardiovascular disease is the biggest cause of death in worldwide. Of the 57 million deaths of the world population, 17.3 million (30\%) deaths are caused by cardiovascular diseases, especially heart attacks (7.3 million) and strokes $(6.2$ million). It is estimated that in 2030 that 23.6 million people worldwide will die of cardiovascular disease.

The treatment that has been done to reduce cholesterol levels is by using synthetic drugs. Synthetic drugs have various disadvantages, among others, expensive prices, side effects caused, and discomfort in treatment. According to 
this reason, searching drug compounds from nature are still needed to do (Masek et al. 2017). Mangrove plants are a very important biological resource in Southeast Sulawesi because they support the lives of endemic animals such as Anoa (Buballus sp) and Sulawesi Eagle and contain antioxidants and nutrients that are potential to be utilized for human welfare (Septiana et al. 2016).

Mangroves grow in extreme environments because of their ability to produce secondary metabolites and act as antioxidants to adapt to various extreme environmental factors on the beach. Analudin, (2018) reported that mangrove leaf tea extract (Sonneratia alba) was able to reduce cholesterol levels in mice in the range of 33.33 to $53.67 \%$. Triterpenoid compounds are known to have various activities such as anticancer, antitumor, antibacterial, antiinflammatory, and anti-cholesterol. Based on the background above, it is necessary to isolate the triterpenoid compound from the leaves of mangrove plant and anticolesterol activity test of the isolated compound.

\section{Materials and Methods}

\section{Material and instrumentation}

The research specimen is mangrove leaves collected from Dulupi vilage, Boalemo district, Gorontalo province, Indonesia in march 2017. The chemicals used in this research were ethyl acetate, n-hexane, methanol, distilled water, silica gel G60 (70-320 mesh), thin layer chromatography (TLC), silica plate, octadecylsilane (ODS) RP- 18, 10\% $\mathrm{H} 2 \mathrm{SO} 4$ in ethanol, alcohol $70 \%$, and cholesterol salt. Instrument were used erlenmeyer, micro tubes, micro pipets, spectrometer uv-vis, IR, I-D and 2-D NMR and evaporator.

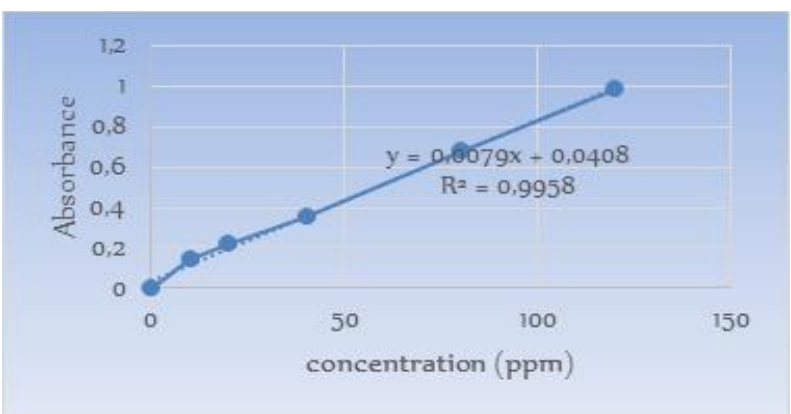

Fig 1. Calibration curva of anti-cholesterol measurement

\section{Extraction and purifycation compound}

Dried mangrove leaves $(1.5 \mathrm{~kg})$ were soaked in 5 $\mathrm{L}$ methanol solvent for 2 days. The shole mixture was then filtered through filter paper and the filtrate was then evaporated under reduce pressure at $55{ }^{\circ} \mathrm{C}$ using a Buchi rotary evaporator.
The extracts were filtered through a cotton plug followed by Whatman filter paper and then concentrated by using a rotary vacum evaporator to provide of methanol crude extract. The methanol extract (10 g) was subjected to liquid chromatography over silica gel using a gradient elution mixture of $n$-hexane-EtOAc (10:0-0:10) as an eluting solvent, yielding 7 fractions (A-G). Fraction C (0.15 g) was subjected to column chromatography over silica gel using a mixture of n-hexane: EtOAc (9:1) as an eluting solvent, affording 30 fractions (E01- E30) and give pure isolated. The purification results of these compounds were determined by TLC on silica gel and ODS with several solvent systems and showed a single spot.

\section{Cholesterol determination}

Reductions of cholesterol levels of isolated compound were determined by comparison with the blank absorbance (cholesterol solution). The stock cholesterol solution was made by mixing cholesterol salt $(100 \mathrm{mg}$ ) in $100 \mathrm{~mL}$ ethanol (1000 ppm) at $45{ }^{\circ} \mathrm{C}$ in water bath. To $0.025,0.05,0.1$, $0.2,0.3$, and $0.4 \mathrm{~mL}$ of cholesterol solution in a cuvette (BRAN ${ }^{\oplus}$ UV cuvette) were added acetic anhydride $(2 \mathrm{~mL})$ and $\mathrm{H}_{2} \mathrm{SO}_{4}(0.1 \mathrm{~mL})$ and diluted with ethanol to a final volume of $5 \mathrm{~mL}$, respectively (blank solutions). To $0.5 \mathrm{~mL}$ of cholesterol solutions were added $0.025,0.05,0.1$, $0.2,0.3$, and $0.4 \mathrm{~mL}$ of isolated compound (1000 ppm), acetic anhydride $(2 \mathrm{~mL})$ and $\mathrm{H}_{2} \mathrm{SO}_{4}(0.1 \mathrm{~mL})$ and diluted with ethanol to a final volume of 5 $\mathrm{mL}$, respectively. After being incubated in the dark for 15 mins at room temperature, the absorbance of the solutions were measured at $423 \mathrm{~nm}$ (Ochani \& D'Mello, 2009; Bachmid et al. 2015). Experiments were carried out independently three times and averages are presented. Statistical analysis was performed by unpaired two-tailed $t$ test (Excel). Differences were considered significant at ${ }^{*} p<0.05,{ }^{* *} p<0.01$ and ${ }^{* * *} p<$ 0.001 .

\section{Test for triterpenoid with Liebermann-Burchard} reaction

A few crystals of compound 1 and 2 were dissolve in chloroform and a few drops of concentrated sulfuric acid were added to it followed by the addition of 2-3 drops of anhydride acetid. In this case isolated compound turned to violet blue and finally formed green color which indicates the presence of triterpenoid (Shanmugapriya et al. 2012; Situmeang et al. 2016; Febrina et al. 2017; Simorangkir et al. 2017). 


\section{Results}

The leaves of $S$. alba was dried and successively extracted with methanol $96 \%$. Therefore, the subsequent phytochemical analysis was focused on the methanol extract, which was chromatographed over a coloumn packed with silica gel G60 with gradient elution. The fractions were repeatedly subjected to normal-phase and reverse-phase column chromatography, yielding one triterpenoid pentacyclic. The compound $(20 \mathrm{mg})$, appeared as white needles.

The results of the phytochemical screening using Liebermann-Burchard reagent showed that the content of pure isolates was thought to be a triterpenoid compound with reddish discoloration. The IR result $(\mathrm{KBr})$ shown in Table 1 . Anticholesterol activity test result shown in Table 2. Calibration curva of anti-cholesterol measurement shown in Fig 1.

lsolated compound: white needles. 'H-NMR (500 $\mathrm{MHz}, \mathrm{CDCl} 3) \delta: 2.22(2 \mathrm{H}, \mathrm{m}, \mathrm{HI}), 1.65(2 \mathrm{H}, \mathrm{m}$,
$\mathrm{H} 2), 3.15(\mathrm{lH}, \mathrm{dd}, \mathrm{J} 15.0,8.4 \mathrm{~Hz}, \mathrm{H} 3), 0.70(\mathrm{lH}, \mathrm{d}$, $\mathrm{H} 5), 1.42(2 \mathrm{H}, \mathrm{m}, \mathrm{H6}), \mathrm{l} .44(2 \mathrm{H}, \mathrm{m}, \mathrm{H} 7), 1.07(\mathrm{HH}$, $\mathrm{H9}), 140(2 \mathrm{H}, \mathrm{m}, \mathrm{HII}), \mathrm{l} .41(2 \mathrm{H}, \mathrm{m}, \mathrm{H} 12), 0.75(\mathrm{lH}$, s, Hi3), $1.20(2 \mathrm{H}, \mathrm{m}, \mathrm{H15}), 1.39(2 \mathrm{H}, \mathrm{m}, \mathrm{H} 16), 0.96$ $(1 \mathrm{H}, \mathrm{d}, \mathrm{H} 18), 2.23(\mathrm{lH}, \mathrm{d}, \mathrm{H} 19), 2.25(2 \mathrm{H}, \mathrm{m}, \mathrm{H} 2 \mathrm{l})$, $2.22(2 \mathrm{H}, \mathrm{m}, \mathrm{H} 22), 0.94(3 \mathrm{H}, \mathrm{s}, \mathrm{H} 23), 0.96(3 \mathrm{H}, \mathrm{s}$, $\mathrm{H} 24), 0.85(3 \mathrm{H}, \mathrm{s}, \mathrm{H} 25), 0.75(3 \mathrm{H}, \mathrm{s}, \mathrm{H} 26), 1.00$ $(3 \mathrm{H}, \mathrm{s}, \mathrm{H} 27), 1.59(3 \mathrm{H}, \mathrm{s}, \mathrm{H} 28), 4.58 \& 4.60(2 \mathrm{H}$, s, H29), $1.69(3 \mathrm{H}, \mathrm{s}, \mathrm{H} 30) .13 \mathrm{CNMR}(125 \mathrm{MHz}$, $\left.\mathrm{CDCl}_{3}\right) \delta: 39.7(\mathrm{CH} 2, \mathrm{Cl}), 28.1(\mathrm{CH} 2, \mathrm{C} 2), 79.7$ $(\mathrm{CH}, \mathrm{C} 3), 40.1(\mathrm{Cq}, \mathrm{C} 4),(\mathrm{CH}, \mathrm{C} 5), 19.6(\mathrm{CH} 2, \mathrm{C} 6)$, $35.7(\mathrm{CH} 2, \mathrm{C} 7), 43.3(\mathrm{Cq}, \mathrm{C} 8), 56.9(\mathrm{CH}, \mathrm{C} 9)$, $38.4(\mathrm{Cq}, \mathrm{C}-10), 26.9(\mathrm{CH} 2, \mathrm{Cl1}), 28.8\left(\mathrm{CH}_{2}, \mathrm{Cl} 2\right)$, $40.2(\mathrm{CH}, \mathrm{Cl} 3), 48.6(\mathrm{Cq}, \mathrm{Cl} 4), 30.9(\mathrm{CH} 2, \mathrm{Cl} 5)$, $38.3(\mathrm{CH} 2, \mathrm{Cl} 6), 49.2(\mathrm{Cq}, \mathrm{Cl}), 52.1(\mathrm{CH}, \mathrm{Cl} 8)$, $50.5(\mathrm{CH}, \mathrm{C} 19), 152.2(\mathrm{Cq}, \mathrm{C} 20), 35.5\left(\mathrm{CH}_{2}, \mathrm{C} 21\right)$, $42.2(\mathrm{CH} 2, \mathrm{C} 22), 31.8\left(\mathrm{CH}_{3}, \mathrm{C} 23\right), 16.2\left(\mathrm{CH}_{3}\right.$, $\mathrm{C} 24), 16.9(\mathrm{CH} 3, \mathrm{C} 25), 16.7(\mathrm{CH} 3, \mathrm{C} 26), 15.2$ $\left(\mathrm{CH}_{3}, \mathrm{C} 27\right), 19.5\left(\mathrm{CH}_{3}, \mathrm{C} 28\right), 110.2\left(\mathrm{CH}_{2}, \mathrm{C} 29\right)$, $22.2\left(\mathrm{CH}_{3}, \mathrm{C} 30\right)$.

Table 1

IR spectrum $(\mathrm{KBr})$

\begin{tabular}{lll}
\hline Wavelength $\left(\mathrm{cm}^{-1}\right)$ & Signal & Fuction Group \\
\hline 3590 & strenght & $\mathrm{OH}-$ \\
2970 & strenght & $\mathrm{C}-\mathrm{H} \mathrm{Sp}^{3}$ \\
1687 & weak & $\mathrm{C}=\mathrm{C}$ \\
1236 & strenght & $\mathrm{C}-\mathrm{O}$ \\
strenght & medium & $\mathrm{C}-\mathrm{H}$ \\
\hline
\end{tabular}

Table 2

Decrease cholesterol Levels in lsolates compound

\begin{tabular}{|c|c|c|c|}
\hline concentration (PPm) & Absorbance & cholesterol & $\begin{array}{c}\text { decrease } \\
(\%)\end{array}$ \\
\hline 5 & 0,722 & 86,23 & 13,7 \\
\hline 10 & 0,598 & 70,53 & 29,4 \\
\hline 20 & 0,443 & 50,91 & 49,0 \\
\hline 40 & 0,356 & 39,90 & 60,1 \\
\hline 60 & 0,276 & 29,77 & 70,2 \\
\hline 80 & 0,222 & 22,94 & 77,0 \\
\hline control (-) & 0,83 & 99,90 & 0,10 \\
\hline
\end{tabular}

\section{Discussion}

The IR spectrum ( $\mathrm{KBr}$ ) of isolated showed characteristic absorption frequencies at 3590 and $1236 \mathrm{~cm}^{-1}$. This spectrum indicated of the $\mathrm{O}-\mathrm{H}$ and $\mathrm{C}-\mathrm{O}$ bond vibrations; the absorption observed at $897 \mathrm{~cm}^{-1}$ was due to an unsaturated out of plane $\mathrm{C}-\mathrm{H}$ vibration (Souza et al. 2011; Situmeang et al. 2018). The $\mathrm{C}=\mathrm{C}$ vibrations was shown around $1687 \mathrm{~cm}^{-1}$ as weakly intense band; stretching and bending vibrations due to methyl groups were represented by the bands at $2935 \mathrm{~cm}^{-1}$ and $1462 \mathrm{~cm}^{-}$ ' and the signal at $1385 \mathrm{~cm}^{-1}$ was due to methylenic vibration (Situmeang et al. 2018).

The 'H-NMR spectrum showed revealed the presence of seven singlet methyl protons at $\delta_{\mathrm{H}}$ $0.75,0.85,0.94,0.96,1.00,1.59$ and $1.69 \mathrm{ppm}$ (integrated for $3 \mathrm{H}$ ). A sextet of one proton at $\delta$ $2.23 \mathrm{ppm}$ ascribable to $19 \beta-\mathrm{H}$ is characteristic of lupeol. The $\mathrm{H}-3$ proton showed a multiplet at $\delta$ $3.15 \mathrm{ppm}$ while a pair of broad singlets at $\delta_{\mathrm{H}} 4.58$ 
and $\delta_{\mathrm{H}} 4.60(\mathrm{lH}$, each) was indicative of olefinic protons at $(\mathrm{H}-29)$. The methylene proton $\mathrm{Sp}^{3}$ showed at $\delta_{\mathrm{H}} 1.20,1.39,1.40,1.41,1.42,1.44,1.65$, 2.22, and $2.25 \mathrm{ppm}$. These assignments are in good agreement for the structure of Lup-20(29)en-3 $\beta$-ol) compound (Silva et al. 2012; Prakash \& Prakash, 2012).

The ${ }^{13} \mathrm{C}$ NMR spectrum showed which seven methyl groups at $[\delta \mathrm{c}: 31.8(\mathrm{C}-23), 19.5$ (C-28), 16.8 (C-25), 16.7 (C-26), 16.2 (C-24), 15.2 (C-27) and $22.2(\mathrm{C}-30)]$; the signals due to an exomethylene group at $[\delta \mathrm{c}$ : $110.2(\mathrm{C}-29)$ and $152.0(\mathrm{C}-20)]$; ten methylene, five methine and five quaternary carbons were assigned with the aid of DEPT $135^{\circ}$ spectrum (Waliullah et al. 2011). The deshielded singnal at $\delta c 79.0$ was due to $\mathrm{C}-3$ with a hydroxyl group attached to it ( $\mathrm{Li}$ et al. 2018). The forgoing spectral analysis and comparison with reported data, led us to propose the structure of isolated compund as a pentacylic triterpenoid (Fig 2).

The confirmation of the structure of isolated was accomplished through the 2D-NMR experiments (COSY and $\mathrm{HMBC}$ ). The ' $\mathrm{H}-{ }^{-} \mathrm{H}$ COSY spectrum of isolated compound exhibited some cross peaks such as between $\delta_{\mathrm{H}} 2.23, \mathrm{H}-19$ and one $\mathrm{Sp}^{3}$ methylene proton signal $\left(\delta_{\mathrm{H}} 2.25, \mathrm{H}-21\right)$ and another $\mathrm{Sp}^{3}$ methine proton signal $\left(\delta_{\mathrm{H}} 0.96, \mathrm{H}-18\right)$; and between oxygenated methine proton signal $\left(\delta_{\mathrm{H}} 1.69, \mathrm{H}-30\right.$ and $\mathrm{Sp}^{3}$ methylene signal $\left(\delta_{\mathrm{H}} 1.65\right.$, $\mathrm{H}-2)^{16-19}$.

In the $\mathrm{HMBC}$ spectrum, the methine proton signal at $\delta_{\mathrm{H}} 3.15(\mathrm{H}-3)$ showed cross peaks with a methyl carbon signal ( $\delta \mathrm{c} 31.8, \mathrm{C}-23)$ by $/ 2$ correlation and a methyl carbon signal $(\delta c 19.6, C-$ $6)$ by $/ 3$ correlation. The sextet methyl signal at $\delta \mathrm{H} 2.23(\mathrm{H}-19)$ showed cross peaks with two methylene carbon signals $\delta c 35.5(\mathrm{C}-21)$ and $\delta c$ 110.2 (C-29)], a methine carbon signal [ $\delta c 52.1$ (C18), a methyl carbon signal $[\delta c 22.2(\mathrm{C}-30)]$ and a quaternary carbon signal $[\delta c 152.2(\mathrm{C}-20)]$. HMBC spectrum of isolate compound shown in Fig 3.

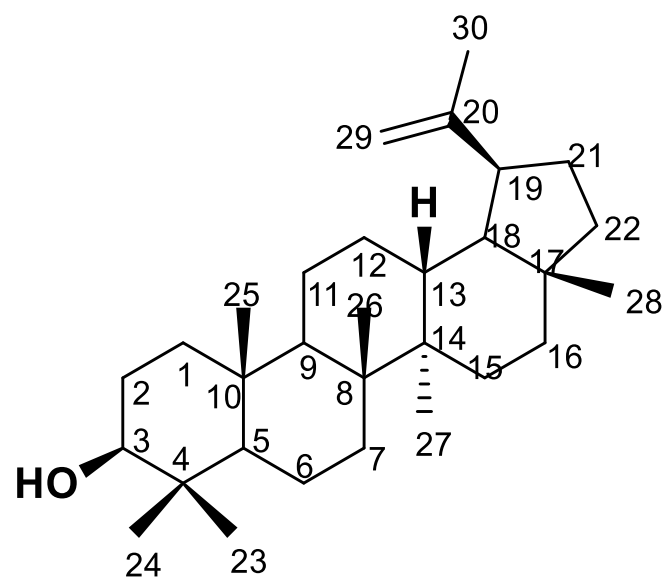

Fig 2. structure of Lup-20(29)-en-3 $\beta$-ol) (Silva et al. 2012).

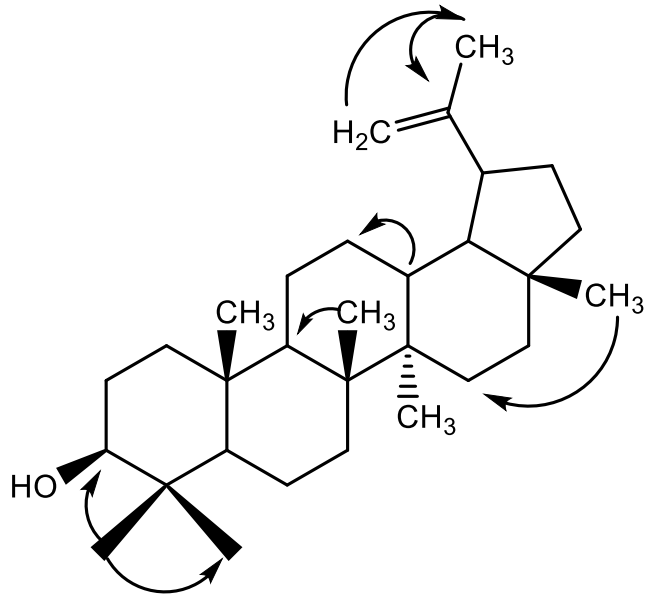

Fig 3. HMBC correlation of isolate compound (Prakash \& Prakash, 2012). 
Measured of cholesterol level reduction was carried out by UV-Vis spectrometer. Measurements begin with the search for wavelengths maximum, with the aim of knowing the wavelength that produces maximum absorbance and to determine the time of measurement of the results of the reaction. The cholesterol (standart) concentration used in this study was $100 \mathrm{ppm}$. The experiment was preceded by measuring the initial concentration of the cholesterol solution. The measurement of the initial concentration every time the measurement aims to determine the concentration of cholesterol solution quantitatively before being added with triterpenoid compound isolates. In the experiments of triterpenoid compounds isolates were measured activity against cholesterol reduction with the aim to determine whether the triterpenoid compound isolates had activity against cholesterol reduction or not. Extracts of triterpenoid compounds in the same concentration series are $5,10,20,40,60$, and $80 \mathrm{ppm}$ respectively. From each concentration series added $0.5 \mathrm{~mL}$ of triterpenoid compound isolates were then put in a test tube which had added $100 \mathrm{ppm}$ cholesterol standard.

After reacting the test solution is left in a dark place protected from light for 15 minutes according to the time taken, left in a dark place protected from light because the solution of cholesterol is photodegradation is not stable to light and will turn into cholesterol (Anggraini \& Ali, 2017). The absorption was measured with a UV-Vis spectrophotometer at a wavelength of 423 $\mathrm{nm}$. After the absorption of the test solution is read then the percent reduction in cholesterol is calculated by means of the initial cholesterol uptake before being added to the sample reduced by cholesterol uptake after being added to the sample solution then divided by the initial cholesterol uptake and multiplied by one hundred percent.

Based on the calculation of the percentage of decline produced, triterpenoid isolates with a concentration of $5 \mathrm{ppm}$ can reduce cholesterol by $13.7 \%$, at a concentration of $10 \mathrm{ppm}$ can reduce by $29.4 \%$, with a concentration of $20 \mathrm{ppm}$ can reduce cholesterol by $40.9 \%$, at a concentration of $40 \mathrm{ppm}$ can reduce cholesterol by $60.1 \%$, at a concentration of $60 \mathrm{ppm}$ can reduce cholesterol by $70.2 \%$, and at a concentration of $80 \mathrm{ppm}$ can reduce cholesterol by $77.0 \mathrm{ppm}$. This is related to the ability of triterpenoid compounds to reduce cholesterol content. Research by Bachmid et al. (2015) reported that ethanol extract of patikan leaves containing triterpenoid compounds were able to reduce doses of 10 and $30 \mathrm{mg} / \mathrm{kgBW}$ with anti-cholesterol activity with a decrease in cholesterol levels of 12 and $71 \%$.

\section{Conclusion}

The results of the phytochemical screening using Liebermann-Burchard reagent showed that the content of pure isolates was thought to be a triterpenoid compound with reddish discoloration. The isolates compound known as triterpenoid pentacyclic (Lup-20(29)-en-3 $\beta$-ol). The results showed that triterpenoid compounds (lupeol) were able to reduce cholesterol from concentrations of $5,10,20,40,60$, and $80 \mathrm{ppm}$ are $13.7 ; 29.4 ; 49.0 ; 60,1 ; 70.2$; and $77.0 \%$ respectively.

\section{Acknowledgments}

The author thank the ministry of research and higher education of the Indonesia Republic for funding this collaboration (RISTEKDIKTI) and Mrs. Fajriah, M.Si as well as Dr. Achmad, M.Si for their help in conducting the NMR spectrum measurement.

\section{References}

Analuddin., Septiana, A., \& Harlis, W. O. (2018). Kandungan antioksidan teh hijau daun mangrove dan uji efektifitasnya sebagai antikolesterol pada mencit. Jurnal $1 \mathrm{lmu}$ dan Teknologi Peternakan Tropis, 5(3), 60-66.

Anggraini, D. l., \& Ali, M. M. (2017). Uji aktivitas antikolesterol ekstrak etanol daun binahong (Anredera cordifolia (Ten) Steenis) secara in vitro. Jurnal Ilmiah Kesehatan MH Thamrin, 9(1), 1-6.

Bachmid, N., Sangi, M. S., \& Pontoh, J. S. (2015). Uji aktivitas antikolesterol ekstrak etanol daun patikan emas (Euphorbia prunifolia Jacq.) pada Tikus Wistar yang hiperkolesterolemia. Jurnal Mipa Unsrat Online, 4(1), 29-35.

Febrina, L., Riris, I. D., \& Silaban, S. (2017). Uji aktivitas antibakteri terhadap Escherichia coli dan antioksidan dari ekstrak air tumbuhan binara (Artemisia vulgaris L.). Jurnal Pendidikan Kimia, 9(2), 311-317, doi: 10.24114/jpkim.v9i2.7621.

Kumar, V.A., Ammani, K., \& Siddhardha, B. (2011). In vitro antimicrobial activity of leaf extract of certain mangrove plants collected from Godavari estuarine of Konaseema delta, India. Int. J. Med. Arom. Plants. 1(2), 132-136. 
Li, X.-J., Zou, Q.-P., Wang, X., Kim, K.-W., Lu, M.-F., Ko, S.-K., ... Liu, X.-Q. (2018). Lupane Triterpenes from the Leaves of Acanthopanax gracilistylus. Molecules, 23(1), 87, doi: 10.3390/molecules23010087.

Masek, A. (2017). Antioxidant and Antiradical Properties of Green Tea Extract Compounds. Int. J. Electrochem. Sci, 12, 6600-6610, doi: 10.20964/2017.07.06.

Musa, W. J., Duengo, S., \& Situmeang, B. (2018). lsolation and characterization triterpenoid compound from leaves mangrove plant (Sonneratia alba) and antibacterial activity test. International Research Journal of Pharmacy, 9(3), 85-89, doi: 10.7897/2230-8407.09347.

Ochani, P. C., \& D'Mello, P. (2009). Antioxidant and antihyperlipidemic activity of Hibiscus sabdariffa Linn. leaves and calyces extracts in rats. Indian Journal of Experimental Biology, 47, 276-282.

Prabhu, V. V., \& Guruvayoorappan, C. (2012). Phytochemical screening of methanolic extract of mangrove Avicennia marina (Forssk.) Vierh. Der Pharmacia Sinica, 3(1), 64-70.

Prakash, C. V. S., \& Prakash, I. (2012). Isolation and structural characterization of lupane triterpenes from Polypodium vulgare. Res. J. Pharm. Sci, 1(1), 23-27.

Shanmugapriya, R., Ramanathan, T., \& Renugadevi, G. (2012). Phytochemical characterization and antimicrobial efficiency of mangrove plants Avicennia marina and Avicennia officinalis. Int J Pharm Biol Arch, 3(2), 348-351.

Septiana, A., Jamili., Harlis, W. O., \& Analuddin, K. (2016). Bioprospectsing: Antioxidant source and habitat of endemic animal of Bubalus sp in Rawa Aopa Watumohai National Park, Indonesia. Malays. Appl. Biol, 45(1), 23-34.
Silva, D.L., David, J., Silva, L., Santos, R., David, J., Lima, L., Reis, P., \& Fontane, R. (2012). Bioactive oleanoat, lupine and ursane triterpenoid acid derivates. Molecules, 17, 1219712205.

Simorangkir, M., Silaban, S., Surbakti, R., Barus, T., \& Simanjuntak, P. (2017). Aktivitas antikanker ekstrak etanol buah Ranti Hitam (Solanum blumei Nees ex Blume) terhadap sel leukimia L1210. Chimica et Natura Acta, 5(1), 31-35, doi: 10.24198/cna.v5.n1.12819.

Situmeang, B. R., Suparman, A. R., Kadarusman, M., Parumbak, A. S., \& Herlina, T. (2018). Isolasi Senyawa Triterpenoid dari Ekstrak Etil Asetat Pirdot (Saurauia vulcani. Kurth). Jurnal Kimia Valensi, 4(2), 93-97, doi: $10.15408 /$ jkv.v4i2.7272.

Situmeang, B., Nuraeni, W., Ibrahim, A. M., \& Silaban, S. (2016). Analysis of secondary metabolite compounds from leaves extract kesambi (Schleichera oleosa) and antioxidant activity test. Jurnal Pendidikan Kimia, 8(3), 164168.

Souza, A. B., Souza, M. G. M. de, Moreira, M. A., Moreira, M. R., Furtado, N. A. J. C., Martins, C. H. G., ... Veneziani, R. C. S. (2011). Antimicrobial evaluation of diterpenes from Copaifera langsdorffii Oleoresin Against Periodontal Anaerobic Bacteria. Molecules, 16(11), 96119619, doi: 10.3390/molecules16119611.

Waliullah, Uddin, G., Rauf, A., Siddiqui, B. S., Rehman, T. U., Azam, S., \& Qaisar, M. (2011). Chemical constituents and biological screening of Grewia optiva Drummond ex Burret Whole Plant. American-Eurasian J Agric \& Environ Sci, $11(4), 542-546$. 